\title{
Field mapping in the Nagssugtoqidian of South-East Greenland
}

\author{
David Bridgwater, F. Bryan Davies, Robin C. O. Gill, \\ Barry E. Gorman, Niels Henriksen and Juan Watterson
}

The 1976 season's work was the first of a reconnaissance mapping programme between $62^{\circ} 30^{\prime} \mathrm{N}$ (Tingmiarmiut) and $68^{\circ} 00^{\prime} \mathrm{N}$ (Kangerdlugssuaq) as the first stage in producing 1:500000 map sheets of this part of the east coast. The work was carried out by a team of six geologists, one geophysicist (G. E. J. Beckmann, see this report) and one field assistant (H. B. Nøhr Hansen) using $5 \mathrm{~m}$ inflatable boats from a 80 ton motor cutter (Tycho Brahe). Reconnaissance work was completed from Sermiligâq $\left(64^{\circ} 54^{\prime} \mathrm{N}\right)$ to inner Kangertigtivatsiaq $\left(66^{\circ} 28^{\prime} \mathrm{N}\right)$ (fig. 19). Approximately one week was spent in the region between Sermilik west of Angmagssalik and Sermiligâq to provide a link between the earlier reconnaissance work of Bridgwater \& Gormsen (1968) and the Birmingham University teams who mapped in the Angmagssalik area between 1967 and 1970 (Wright et al., 1973). North of $66^{\circ} 00^{\prime} \mathrm{N}$ in Sermilik and $66^{\circ} 15^{\prime} \mathrm{N}$ on the outer coast work was prevented by ice which remained impassable until late August. A total of 35 days was available.

\section{Geological summary}

The region visited occurs between 200 and $300 \mathrm{~km}$ north-east of the boundary of the Nagssugtoqidian mobile belt in South-East Greenland (Bridgwater \& Gormsen, 1969). This belt consists of Archaean amphibolite and granulite-facies gneisses (Bridgwater et al., 1976) intruded by numerous Early Proterozoic dykes and tectonically reworked during the Proterozoic deformation (Table 2). Close to Angmagssalik the tectonically reworked gneisses are cut by a series of Proterozoic intrusions ranging from the syn-tectonic leuconoritecharnockite complex at Angmagssalik to the post-tectonic basic, intermediate and potash granite intrusions to the north and west of Angmagssalik. The emplacement of the syntectonic basic and intermediate suite led to high-grade metamorphism and considerable partial melting in parts of the gneiss complex. Two sets of Tertiary dykes occur in the area. These show a marked concentration near the outer coast comparable to that described by Wager \& Deer (1938).

Apart from the regional distribution of major lithological units the main problems studied in the field were those associated with the Nagssugtoqidian tectonic reworking of the older gneiss complex. By analogy with the chronology established on the west coast (Watterson, 1974), the various phases of Nagssugtoqidian movements were divided into two groups according to their age relative to the Early Proterozoic basic dykes:

Nag. 1 deformation - an early deformation during which a new schistosity was impressed on the Archaean complex. This pre-dates, or possibly overlaps locally with, the emplacement of the Proterozoic basic dyke swarms.

Nag. 2 deformation includes those movements post-dating the basic dykes. Nag. 1 deformation occurs throughout the area mapped and is commonly concentrated in distinct belts within which the Archaean gneisses acquired a strong schistosity. Nag. 2 deformation 


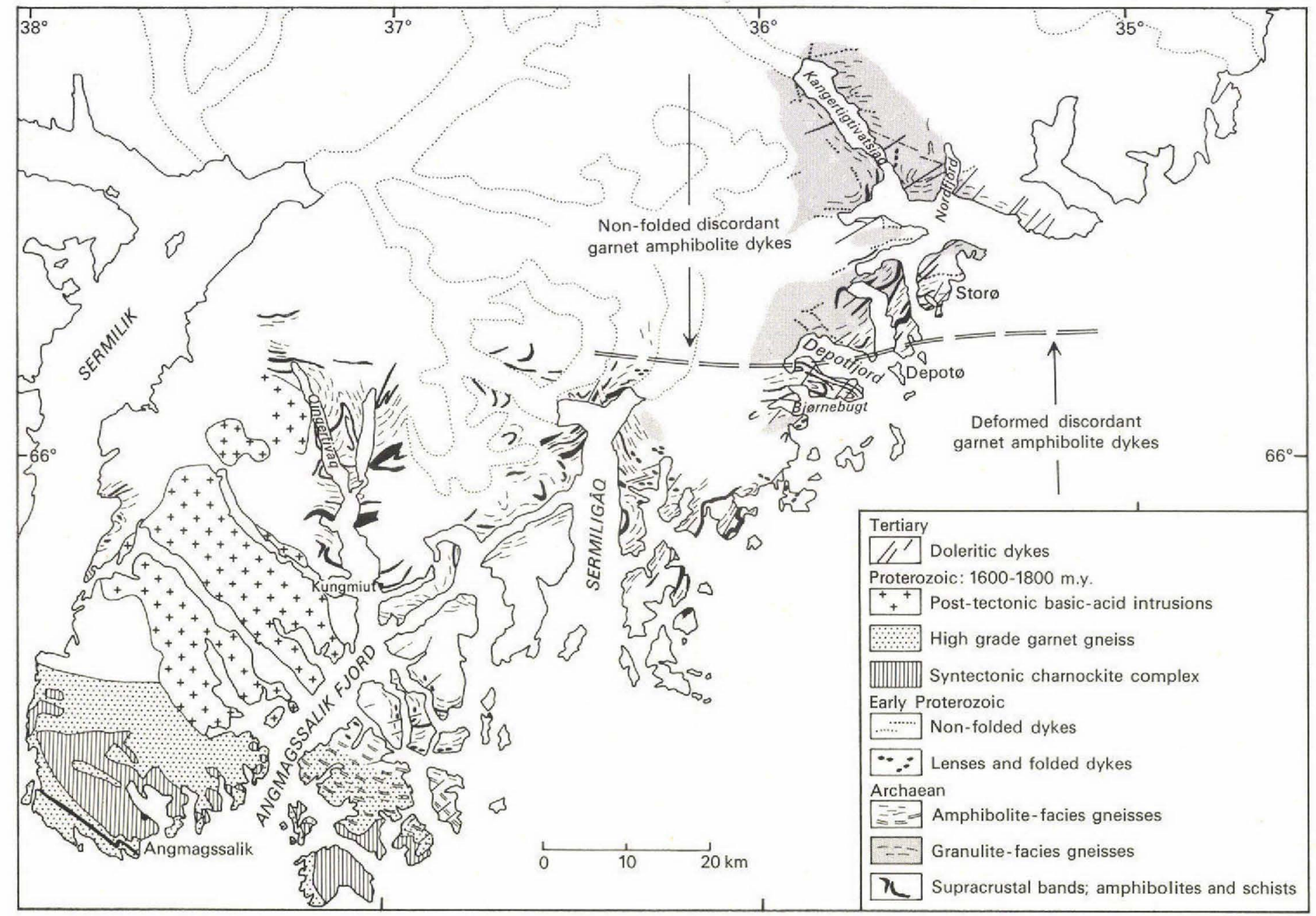

Fig. 19. Geological sketch map of the coast north-east of Angmagssalik, South-East Greenland. 
Table 2. Chronological table of the major events in the region north-east of Angmagssalik, South-East Greenland

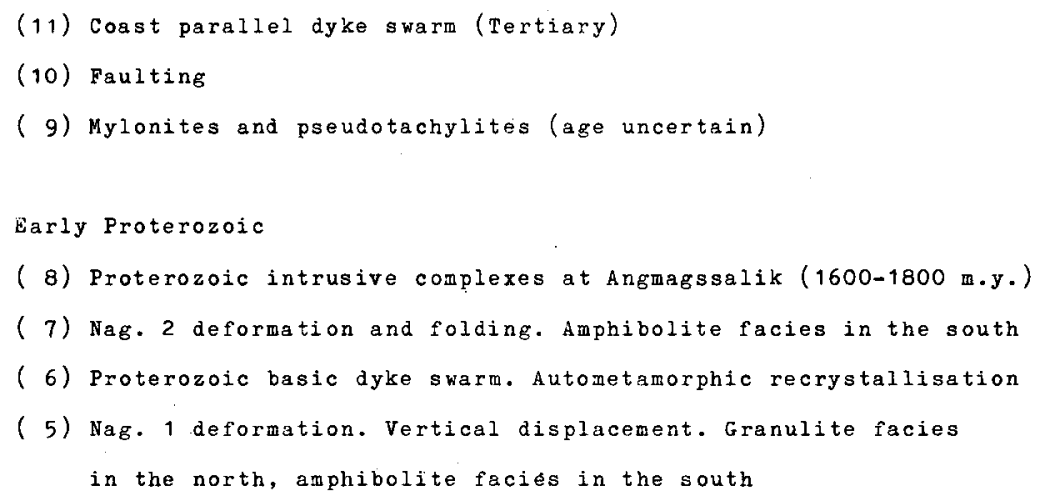

affected mainly the southern part of the area where it is the main control on the distribution of rock types as seen on the regional maps. In the northern part of the area Nag. 2 deformation is less apparent and the main structures appear to be complex Archaean folds little modified by later movements except for minor shear belts.

\section{Archaean gneisses}

Approximately 85 per cent of the gneiss complex consists of quartzo-feldspathic rocks of granodioritic to tonalitic composition which are thought to have been derived from plutonic igneous suites. These contain abundant inclusions and layers of earlier rocks varying in scale from centimetres to mappable units tens of kilometres in length and up to several hundred metres wide. Where these remnants can be identified they are derived either from earlier supracrustal rocks, or from layered basic igneous rocks among which members of an ultramafic - gábbro-anorthosite - anorthosite suite predominate. Major supracrustal horizons dominated by pelitic schists are more conspicuous in the southern part of the area mapped. Although swarms of Archaean amphibolite dykes occur locally in the grey gneisses 
there is no definite evidence that these can be used to distinguish more than one major time-unit of the quartzo-feldspathic gneisses and we do not regard any of the quartzofeldspathic gneisses as proven basement to the supracrustals.

\section{Quartzo-feldspathic gneisses}

Variation in the character of the quartzo-feldspathic gneisses is largely the result of post-emplacement recrystallisation, during the various episodes of Nagssugtoqidian deformation. There is however evidence that the gneisses varied in lithology and metamorphic facies from one part of the area to another prior to the injection of the Proterozoic dyke swarm. Gneisses from the islands south and east of Kungmiut are relatively little affected by younger deformation and preserve many primary intrusive features. They appear to have been derived from a syn-tectonic calc-alkaline suite of relatively mafic tonalites and granodiorites with minor amounts of hornblende diorite and feldsparphyric granodiorite. In Kangertigtivatsiaq and on Storø $\left(66^{\circ} 13^{\prime} \mathrm{N}\right)$ some of the quartzo-feldspathic gneisses were mobile under granulite-facies conditions and contain primary orthopyroxene. In the same area granulite-facies pegmatites cut earlier foliated gneisses which appear to have formed by the prograde metamorphism of earlier amphibolite-facies gneisses.

\section{Supracrustal rocks}

Rocks of supracrustal origin show considerable range in composition. The most widespread rocks (although not necessarily dominant in individual successions) are amphibolitic rocks of basaltic composition. In the amphibolite-facies areas these consist largely of amphibole, quartz, plagioclase with or without diopside, anthophyllite and garnet. The garnet frequently shows a well-developed symplectic rim of labradorite. In the granulitefacies rocks to the north of the area the basic layers contain diopside, hypersthene, garnet and hornblende.

A wide variety of rusty-weathering metasedimentary rocks (including pelites and quartzite layers up to 20 metres thick) often form the margins of large supracrustal bands and are spatially associated with the amphibolites. The pelitic rocks are invariably garnet-bearing and frequently contain sillimanite, particularly along schistose partings. In the south between Sermiligâq and the head of Angmagssalik Fjord, highly-aluminous pelitic rocks were found, containing large garnet and lineated kyanite crystals (up to $5 \mathrm{~cm}$ ), the latter with local overgrowths of fibrolite.

Thin diopside- and grunerite-bearing quartz-banded ironstones, calc-silicate layers and graphite schists are found in thick supracrustal successions. Impure marbles were found as float and in place in one 20 -metre supracrustal band. Sub-concordant plagioclase pegmatite sheets are common within pelitic horizons near the margins of thick supracrustal bands, locally forming up to 50 per cent of the exposure.

Sulphide mineralisation is particularly abundant in rusty-weathering quartzites and friable pelitic rocks adjacent to quartz ironstone layers. Molybdenite is present.

Many of the supracrustal bands can be traced for tens of kilometres providing the only useful marker horizons for recognition of large-scale folds. The margins are transgressed irregularly by the host gneisses which raft off fragments and penetrate into the successions. 
The thickness of the mapped bands and the proportion of the lithologies within single bands is therefore regarded as fortuitous and not representative of a complete original supracrustal succession.

Basic igneous intrusions of the gabbro-anorthosite suite

Broken up fragments of layered hornblende diopside (hypersthene) plagioclase rock have been noted as inclusions within the quartzo-feldspathic gneisses from scattered localities throughout the area. They are petrologically comparable to the gabbro-anorthosites of the Archaean block, and some fragments show the characteristic plagioclase augen textures known for example from the Fiskenæsset region of the west coast. Compared with the major occurrences in the Archaean block there is a smaller proportion of anorthosite sensu stricto among the outcrops discovered this summer. Particularly notable is a coherent raft of layered basic igneous rock some hundred metres in extent, extensively veined by granitic gneisses, in Nordfjord and on the north coast of the sound separating Angmagssalik $\emptyset$ from the mainland. Fragment trains occur over a comparatively large area on the east coast of Sermilik and within the garnet gneisses forming the border zone to the Angmagssalik igneous complex.

\section{Ultramafic rocks}

Ultramafic rocks occur as small lenses within the supracrustal units. They locally show a bladed olivine texture interpreted as a metamorphic growth of olivine under granulite-facies conditions (Collerson, et al., 1976). Ultramafic rocks also occur independently of recognisable supracrustal rocks as coarse-grained enstatite-bearing inclusion trains in the gneisses commonly tens of metres long and up to 1-2 metres wide. Individual inclusions are commonly rounded and range in size from 10 to $200 \mathrm{~cm}$. They show a thin reaction rim of biotite against the surrounding gneisses. In some localities the inclusion trains appear discordant to earlier fabrics in the gneisses and resemble highly disrupted sills or dykes. Some of the fragments show unusually coarse grain size with individual poikilitic enstatite crystals up to several decimetres. This type of inclusion is more common in granulite-facies gneisses than elsewhere and the characteristic outcrop pattern of the inclusion trains can give a first field indication that a particular suite of amphibolite-facies gneisses have been retrogressed from higher grade rocks.

\section{Proterozoic metadolerite dykes and their use as time markers}

Basic dykes, or the disrupted remnants of basic dykes, occur throughout the area of Archaean gneisses. They have not been recorded from within the Angmagssalik leuconorite complex. The post-tectonic intrusions in the area close to Angmagssalik contain inclusions of gneiss cut by basic dykes which do not continue into the younger host granites. A few recrystallised and veined dykes were noted in the garnet gneisses surrounding the Angmagssalik leuconorite complex. The dykes represent the northern continuation of the swarms recorded south of Angmagssalik where they are known to consist of several generations of early Proterozoic basic intrusions ranging from early norites and olivine gabbros to younger 
iron-rich tholeiites, intruded into the Archaean complex. They are regarded as equivalent to the Kangâmiut dyke swarm of the west coast and the Scourie dykes of Scotland, with which they share many chemical and mineralogical features.

\section{Characteristics of the Proterozoic basic dykes}

Dykes map out as linear features only in those areas not affected by significant Nag. 2 folding. Four significant primary features of the dykes are given below, all of which are known from occurrences of the swarm south-west of Angmagssalik and on the west coast.

(1) Primary pinch and swell form when emplaced into amphibolite-facies rocks with pronounced tectonic fabrics.

(2) Parallel-sided form when emplaced in granulite facies or massive amphibolite facies not affected by Nagssugtoqidian movements. In some cases dykes exhibit an intense network of high-angle apophyses and show sudden changes in direction which obscure the main trend.

(3) A single example of a composite dyke with basic margins and a foliated felsic centre was noted intruding granulite-facies gneisses in Bjørnebugt.

(4) Dyke distribution controlled by the nature of the country rock.

In the amphibolite facies areas where a good tectonic fabric is often developed dykes are numerous and individuals in many cases can be seen to have been emplaced along individual shear zones or in zones of high Nag. 1 strain. In the more massive granulite-facies gneisses the dykes are considerably fewer although individual bodies may reach 50 to $100 \mathrm{~m}$ in width. The primary mineral assemblages in the dykes are largely of autometamorphic origin, and interpreted as a direct consequence of the dykes being emplaced in country rocks at metamorphic temperatures, allowing partial or complete sub-solidus recrystallisation at temperatures between the solidus and that of the country rocks. The primary assemblage thus usually includes garnet, often in corona structures and showing reaction relations with plagioclase, diopside, hypersthene and amphibole (cf. Griffin \& Heier, 1973). The centres of the larger dykes frequently contain garnet- pyroxene assemblages while the outer margins to the dykes consist of garnet amphibolite and amphibolite.

\section{Proterozoic intrusive complexes}

The syntectonic leuconorite-charnockite complex and associated garnet gneisses (Bridgwater \& Gormsen, 1968; Wright et al., 1973) were briefly revisited. We now interpret this body as being of Proterozoic rather than Archaean age since remnants of basic dykes have been identified in the garnet gneisses surrounding the basic suite. A preliminary U-Pb zircon age of $1827 \mathrm{~m}$.y. has been obtained from a charnockitic sample (GGU 99201) collected from Angmagssalik town quarry (R. Chessex, personal communication, 1974).

The post-tectonic Proterozoic intrusive suite was re-examined on both coasts of the sound separating Angmagssalik $\emptyset$ from the mainland and in the north-west arm of Angmagssalik Fjord (Qingertivaq). Suites varying from early hornblende-biotite-sphene diorites to potash-rich granites poor in mafics were collected at both localities for $\mathrm{Rb}-\mathrm{Sr}$ isotope and petrological studies. 


\section{Pseudotachylites}

Several fracture zones with pseudotachylite occur in Nordfjord. This brittle deformation is superimposed on mylonites resulting from intense ductile deformation confined to the same zones.

In the most intense swarm of pseudotachylites, seen on the west coast of Nordfjord, the pseudotachylite veins occur within, and parallel to, a several hundred metre wide retrogressed ductile shear zone bordered by granulite-facies rocks. This shear zone strikes $110^{\circ}$ with a north-side down movement similar to other zones established as being of Nag. 1 age.

\section{Tertiary dykes}

Unmetamorphosed fine-grained brown weathering dolerite dykes with polygonal jointing intrude the basement, generally as steep bodies. Near the outer coasts they average 1-2 dykes per kilometre (average thickness 10-20 m). Further inland the swarm dies out. No systematic changes in dip (cf. Wager \& Deer, 1938) have been recognised. Some individual dykes can be traced for tens of kilometres. Dykes of the main swarm are broadly coast parallel striking at $020^{\circ}-040^{\circ}$. A second group striking at $060^{\circ}-080^{\circ}$ occurs locally, particularly in the south of the area related to the marked change in direction of the coast. The relative ages of the two groups have not been determined, but both are presumed to be of Tertiary age. The geometry of the apophyses of dykes in homogeneous country rocks are consistent for each set and vary from 'steps' in the dykes to en echelon sigmoidal forms on outcrop scale. Apophyses of dykes trending $020^{\circ}$ suggest dyke emplacement into sinistral shear fractures, whereas those of the $060^{\circ}-080^{\circ}$ set suggest emplacement into dextral shear fractures. There is a marked concentration of dykes in NE-trending fault zones cutting the gneisses on the outer coast near Depotø. In these $200-500 \mathrm{~m}$ wide areas of fractured gneisses the dykes commonly change direction abruptly and show marked thickness variations.

\section{Metamorphic and structural history}

Facies distribution

The area can be divided into five metamorphic zones from south-west to north-east.

(1) A belt of granulite-facies garnet-rich gneisses up to $15 \mathrm{~km}$ north of the Angmagssalik leuconorite complex. These rocks commonly show prograde recrystallisation and partial remobilisation interpreted by us as a contact metamorphic phenomenon associated with the Proterozoic emplacement under regional metamorphic conditions of a large basic body into a mixed suite of Archaean metasediments and quartzo-feldspathic gneisses.

(2) A zone of amphibolite-facies gneisses extending from the east side of Angmagssalik Fjord to Sermiligâq.

(3) A transitional zone of amphibolite-facies gneisses in which there are occasional isolated outcrops of granulite-facies gneiss. The southernmost outcrops of granulite facies occur at approximately $66^{\circ} 00^{\prime} \mathrm{N}$ in a fjord north-east of Sermiligâq. More extensive outcrops of granulite-facies rocks occur in Bjørnebugt $\left(66^{\circ} 03^{\prime} \mathrm{N}\right)$.

(4) A zone of predominantly granulite-facies rocks extending from Depotfjord $\left(66^{\circ} 07^{\prime} \mathrm{N}\right)$ to the head of Kangertigtivatsiaq $\left(66^{\circ} 28^{\prime} \mathrm{N}\right)$. In this area Proterozoic (Nagssugtoqidian) deformation is restricted to narrow shear belts. 
(5) An area of amphibolite-facies gneisses occupying the outer part of Kangertigtivatsiaq and which is thought to extend northwards.

South of Sermiligâq, Archaean gneisses found in areas of low Proterozoic deformation show no evidence of having been at a higher grade than amphibolite facies. Supracrustal horizons are comparatively well preserved and may measure up to a kilometre across strike. Igneous textures and intrusive relations between different phases are seen in the quartzofeldspathic rocks, all of which are in the same metamorphic facies. Consequently the granulite-facies gneisses in the Kangertigtivatsiaq fjord area show a more complex history. Outcrops of 'blebby gneisses', in which an earlier fabric has been partially destroyed under high-grade conditions with concomitant segregation of mafic minerals into coarse clots (garnet and orthopyroxene rimmed by biotite and chlorite), are common. We associate this feature with prograde recrystallisation and local mobilisation of amphibolite-facies gneisses under granulite-facies conditions.

Effects of Proterozoic deformation on the Archaean complex

Nag. 1 deformation. In the southern amphibolite-facies area the gneisses show varying degrees of deformation and on associated development of an $L-S$ tectonic fabric which unless reorientated during Nag. 2 folding, has a predominant ESE strike and steep NE dip. Stretching lineations within this fabric are mostly reclined. Zones of varying intensities of deformation alternate on scales varying from centimetres to several hundred metres. The most intensely deformed zones, in which gneisses have a platy or flaggy aspect, comprise usually less than 25 per cent of the whole.

Between the zones of marked Nag. 1 deformation there are large augen of unmodified Archaean gneisses. Some of these augen contain complex fold patterns which at their margins are modified by the Nag. 1 deformation so that the earlier structures are deformed into parallelism. The transitions between zones of differing fabric intensity are narrow relative to the width of the zones where these are of small scale (up to $10 \mathrm{~m}$ ). Where unaffected by later folding, the change in attitude of gneiss banding allows a sense of displacement to be determined across what are regarded as zones of simple shear deformation. A north-down (or normal) fault sense of displacement seems most common although not exclusive.

Within the transitional and granulite-facies zones ( 3 and 4) Nag. 1 deformation is closely associated with downgrading from granulite to amphibolite facies. This is best displayed in retrogressed shear zones. However the Nag. 1 tectonite fabrics are confined to rocks with amphibolite-facies assemblages as fabrics interpreted as representing low and moderate Nag. 1 strains also occur in rocks in which granulite-facies assemblages are stable. Good examples of this relationship is seen on Storø and in the inner parts of Kangertigtivatsiaq.

In this respect the Nag. 1 shear belts in the present area combine characters of two contrasting types described from the west coast (Bak et al., 1975), i.e. the Ikertôq belt in which Nag. 1 deformation is always associated with retrogression and the Nordre Strømfjord belt in which granulite-facies assemblages remained stable during deformation. We interpret the differences between the present area and the Ikertôq and Nordre Strømfjord belts as due to a combination of three factors:

6 Rapport nr. 85 
(1) The facies inherited from Archaean metamorphism,

(2) The temperature reached in each area during Nag. 1 deformation,

(3) The failure to form retrogressive assemblages in granulite-facies rocks, even when held for extensive periods under amphibolite-facies conditions, unless recrystallisation is initiated or permitted by deformation.

In the region described in this report we suggest a temperature gradient existed during Nag. 1 deformation with higher temperatures towards the north. The granulite facies amphibolite facies isograd occurred approximately along the southern boundary of the present granulite outcrop. South of this line deformation produced retrograde amphibolite assemblages with small areas of less deformed rock retaining metastable granulite-facies mineral assemblages. North of this line granulite-facies assemblages remained stable even during Nag. 1 deformation. The occurrence of some retrograded shear zones even in this area is interpreted as the result of the latest Nag. 1 events occurring when the declining temperature had fallen below the granulite-facies isograd.

Nag. 2. deformation. Following emplacement of the regional dyke swarm, tectonite fabrics and folds varying in wavelength from tens of metres to several kilometres were formed in many parts of the region. These folds are most intense in, and small-scale folds probably restricted to, areas affected by Nag. 1 deformation. They are particularly well developed in the amphibolite-facies area between Sermiligâq and Storø. On a regional scale the age of this folding is shown by the folding of the dykes and of the wider zones of Nag. 1 deformation. On an outcrop scale the Nag. 2 folding is seen by the effects on smaller dykes and on the Nag. 1 fabrics. Deformation associated with this folding is relatively slight as axial plane fabrics are not developed in minor folds although axial planar mica fabrics have been observed. This contrasts with structures west of Angmagssalik nearer the border of the Nagssugtoqidian where post-dyke deformation commonly resulted in intense shearing within shallow dipping shear zones (Bridgwater \& Gormsen, 1968, 1969).

The most intense effects of the $\mathrm{Nag} .2$ folding are seen in the disruption and migmatisation of the dykes. The degree to which the dykes are disrupted varies over relatively short distances and complete amphibolitisation is common in dykes of less than $\mathbf{4 m}$ thickness in the area south of Depotfjord. Square-ended boudinage of dykes has been seen only at one locality (in Sermilik) and elsewhere Nag. 2 deformation of dykes has most commonly accentuated the primary pinch and swell form of the dykes (see below).

Mesoscopic and minor Nag. 2 folds have NE-striking axial planes dipping steeply to the NW, usually with axes plunging at low angles to the NE. Some larger folds defined by the trace of persistent supracrustal layers do not conform to this pattern owing to interference with earlier folds of Archaean age.

In the area mapped this year Nag. 2 folds on any scale rarely have interlimb angles of less than $80-90^{\circ}$ but although accompanied by only slight deformation compared with that of Nag. 1, the Nag. 2 folding had a major effect on the disposition of rock units and hence on the map pattern. Fabrics developed during Nag. 2 deformation in the region north of Sermiligâq are considerably less intense than those developed in the shallow-dipping E-W belts of post-dyke shearing which characterises the border zone of the Nagssugtoqidian mobile belt south-west of Angmagssalik. Systematic changes in regional metamorphic assemblages associated with Nag. 2 folding has not been noted and it is assumed that amphibolite-facies conditions prevailed during this event in the area north of Angmagssalik. 


\section{References}

Bak, J., Sørensen, K., Grocott, J., Korstgaard, J. A., Nash, D. \& Watterson, J. 1975: Tectonic implications of Precambrian shear beltsin western Greenland. Nature, Lond. 254, 566-569.

Bridgwater, D. \& Gormsen, K. 1968: Precambrian rocks of the Angmagssalik area, East Greenland. Rapp. Gronlands geol. Unders. 15, 61-71.

Bridgwater, D. \& Gormsen, K. 1969: Geological reconnaissance of the Precambrian rocks of southeast Greenland. Rapp. Grønlands geol. Unders. 19, 43-50.

Bridgwater, D., Keto, L., McGregor, V. R. \& Myers, J. S. 1976: Archaean gneiss complex of Greenland. In Escher, A. \& Watt, W. S. (edit.) Geology of Greenland, 18-75. Copenhagen: Geol. Surv. Greenland.

Collerson, K. D., Jesseau, C. W. \& Bridgwater, D. 1976: Contrasting types of bladed olivine in ultramafic rocks from the Archaean of Labrador. Can. J. Earth Sci. 13, 442-450.

Griffin, W. L. \& Heier, K. S. 1973: Petrological implications of some corona structures. Lithos 6, 315-335.

Wager, L. R. \& Deer, W. A. 1938: A dyke swarm and crustal flexure in East Greenland. Geol. Mag. 75, $39-46$.

Watterson, J. 1974: Investigations on the Nagssugtoqidian boundary in the Holsteinsborg district, central West Greenland. Rapp. Grønlands geol. Unders. 65, 33-37.

Wright, A. E., Tarney , J., Palmer, K. F., Moorlock, B. S. P. \& Skinner, A. C. 1973: The geology of the Angmagssalik area, East Greenland and possible relationships with the Lewisian of Scotland. In Park, R. G. \& Tarney, J. (edit.) The Early Precambrian of Scotland and related rocks of Greenland. 157-177. Birmingham U.P.

F.B.D.,

5 Silver Street,

Gastard,

Corsham Wilts,

U.K.

B.E.G.,

Department of Geology,

University of Western Ontario,

London,

Ontario N6A 5B7,

Canada.
R.C.O.G., Department of Geology and Mineralogy, Oxford University $O X 13 P R$, U.K.

J.W., Jane Herdman Laboratories of Geology, University of Liverpool, Brownlow Street, Liverpool L69 $3 B X$,

U.K. 